\title{
5
}

\section{Good Call: Extending Liability for Employment Contraventions Beyond the Direct Employer}

\author{
Tess Hardy ${ }^{1}$
}

\section{Introduction}

A raft of recent inquiries and investigations have revealed that noncompliance with employment standards regulation ${ }^{2}$ is a pressing problem in Australia. ${ }^{3}$ While there are many factors which may have contributed to a lack of employer compliance, including the growing vulnerability of segments of the workforce and a decline in unionisation, this chapter will focus on some of the most critical limits of the Fair Work Act 2009 (Cth) $(F W A c t)$. The inquiry into the 7-Eleven franchise network undertaken by the Office of the Fair Work Ombudsman (FWO) in 2016 will be

\footnotetext{
Senior Lecturer, Melbourne Law School.

Unless otherwise specified, the terms 'employment standards' or 'workplace standards' are used to refer to the regulation governing minimum rates of pay, hours of work, and leave and termination entitlements, including by way of the Fair Work Act 2009 (Cth), modern awards and enterprise agreements.

3 See, for example, Senate Education and Employment References Committee, Inquiry into the Impact of Australia's Temporary Work Visa Programs on the Australian Labour Market and on the Temporary Work Visa Holders (Final Report, 17 March 2016); Caro Meldrum-Hanna and Ali Russell, 'Slaving Away', Four Corners, 4 May 2015; Adele Ferguson and Klaus Toft, '7-Eleven: The Price of Convenience', Four Corners, 31 August 2015.
} 
used to illustrate some of the key regulatory challenges. ${ }^{4}$ In exploring possible reform options, this chapter will consider whether, and in what circumstances, liability for employment standards contraventions should extend beyond the direct employer. In particular, this chapter is especially focused on the extent to which so-called 'lead firms' should be held liable for employment contraventions taking place in their supply chain, corporate group or franchise network. ${ }^{5}$ The paper will conclude with some preliminary observations regarding the merits (or otherwise) of the Fair Work Amendment (Protecting Vulnerable Workers) Bill 2017 (Cth) ('Vulnerable Workers Bill') which was introduced into federal parliament on 1 March 2017.

\section{Limitations of the Current Regulatory Regime}

The FW Act largely continues to reflect the unitary conception of the 'employer' - the idea that there is only one person or entity responsible for setting and complying with employment conditions. ${ }^{6}$ However, there is growing evidence to suggest that key conditions of employment - such as recruitment, pay, working hours, supervision and termination - may be determined by a number of organisations outside and beyond the direct employer as a result of outsourcing, subcontracting, labour hire or franchising.

While these various commercial arrangements are all legitimate business strategies, the fragmentation of corporate structures and working arrangements into loosely connected networks has blurred the lines of responsibility for ensuring workplace compliance. It has also made the enforcement of employment standards regulation undoubtedly more complex and potentially less effective. ${ }^{7}$ Civil remedy litigation is increasingly foiled by the fact that the putative employer entity may

4 Office of the Fair Work Ombudsman, 'A Report of the Fair Work Ombudsman's Inquiry into 7-Eleven' (Australian Government, April 2016) (7-Eleven Inquiry).

5 The term 'lead firm' is used in a broad sense to capture those companies which sit at the top of supply chain, the head of a corporate group or at the apex of a franchise network. In reality, identifying only one lead firm may not be straightforward, particularly where the putative lead firm is part of a larger corporate group. For further discussion of this issue, see Tess Hardy, 'Who Should Be Held Liable for Workplace Contraventions and on What Basis?' (2016) 29 Australian Journal of Labour Law 78.

6 See generally Jeremias Prassl, The Concept of the Employer (Oxford University Press, 2015).

7 David Weil, The Fissured Workplace: Why Work Became So Bad for So Many and What Can Be Done to Improve It (Harvard University Press, 2014). 
elect to liquidate or deregister the relevant employing corporation. This not only has the effect of rendering the employer immune from the legal consequences of its non-compliance, it may mean that underpayments are never fully recovered. ${ }^{8}$ Moreover, targeting the direct employer may not be effective in addressing some of the systemic drivers of employer noncompliance, which may be determined by more powerful firms positioned higher in the supply chain, the corporate group or the franchise network.

It seems that the laws which were originally intended to protect workers from exploitation may now perpetuate such problems 'by focusing regulatory attention on the wrong parties'. ${ }^{9}$ By positioning the direct employer entity as the primary wrongdoer, the civil remedy regime established under the FW Act does not fully account for the disaggregation of employer functions described above. Rather, the existing legal framework appears to permit lead firms to 'have it both ways' ${ }^{10}$ - that is, firms positioned at the top of a supply chain, at the head of a corporate group, or at the apex of a franchise network, may exercise high levels of control over the performance of work, and yet remain legally insulated from the problems this may create. This particular issue was highlighted in the FWO's recent public inquiry into allegations of widespread underpayment of workers in the 7-Eleven franchise network.

\section{The FWO's Inquiry into the 7-Eleven Franchise Network}

A significant component of the FWO's current compliance and enforcement strategy is the conduct of formal, public inquiries. These in-depth inquiries are generally prompted by allegations or concerns about systemic employer non-compliance in an industry, region, supply chain or labour market. They normally entail the regulator undertaking a detailed examination of the drivers of compliance behaviour through site visits, interviews and payroll audits. Specific focus is placed on the role of lead firms. At the conclusion of an inquiry, a written report is made publicly available which sets out the key findings, the regulator's recommendations, and any actions taken including whether the regulator has (or is likely to) initiate enforcement litigation against one or more persons. ${ }^{11}$

8 See, for example, Fair Work Ombudsman v Haider Pty Ltd [2015] FCCA 2113 (30 July 2015).

9 Weil, above n 7, 4 .

10 Ibid. 14

11 Fair Work Ombudsman, Annual Report 2014-15, 31. 
The FWO's inquiry into the 7-Eleven franchise network sought to better understand the regulatory role played by head office of the 7-Eleven franchise, namely 7-Eleven Stores Pty Ltd ('7-Eleven Stores'), as well as its franchisees and their employees. The FWO's report makes clear that 7-Eleven Stores 'had a reasonable basis on which to inquire and act' ${ }^{12}$ into allegations of franchisee non-compliance with employment standards. In particular, the regulator noted that, for at least five years prior to the public airing of these issues, 7-Eleven Stores was aware that multiple outlets within its network had deliberately sought to evade employment regulation through the falsification of employment and payroll records.

Notwithstanding the mounting evidence of widespread workplace contraventions in this period, the FWO found that 7-Eleven head office largely failed to take any substantive steps to curb employer noncompliance. In particular, the FWO noted that while 7-Eleven Stores exercised a high degree of control over its franchisees, it did not implement any significant changes to its franchise model, its existing monitoring mechanisms or its payroll systems. Indeed, despite the pattern of poor compliance behaviour across its network, 7-Eleven Stores expressly declined to participate in the FWO's voluntary franchise program which was specifically designed to leverage the franchise relationship in a way that enhanced employment standards compliance amongst franchisees. ${ }^{13}$ In short, the FWO found that while 7-Eleven Stores ostensibly promoted compliance with workplace standards, it 'did not adequately detect or address deliberate non-compliance and as a consequence compounded it'. ${ }^{14}$

Notwithstanding this finding, the FWO ultimately determined that 7-Eleven Stores' failure to do more or act earlier did not give rise to any legal liability. In particular, the FWO concluded that it did not have sufficient probative evidence to pursue 7-Eleven Stores under the accessorial liability provisions of the $F W A c t .{ }^{15}$ Accordingly, the regulator decided not to initiate civil remedy litigation against the lead firm in this instance.

13 Ibid. 10. See also Tess Hardy, 'Brandishing the Brand: Enhancing Employer Compliance through the Regulatory Enrolment of Franchisors' (Paper presented at the Labour Law Research Network Conference, Amsterdam, 25-27 June 2015).

14 7-Eleven Inquiry, above n 4, 4.

15 FW Act s 550. 
Initially, the conclusion reached by the FWO in this inquiry - that 7-Eleven Stores was not liable for the employment contraventions which had taken place in its network - was not especially concerning from a regulatory perspective given that the 7-Eleven head office had already taken a range of far-reaching compliance measures in the intervening period, including:

a. reviewing key aspects of the franchise model;

b. setting up an independent panel to receive and process wage claims; and

c. introducing more rigorous and accountable monitoring and payroll systems. ${ }^{16}$

While these types of voluntary measures are valuable, it is somewhat telling that these proactive steps were only taken by 7-Eleven Stores after the media story broke and the brand had suffered a significant public bruising. Indeed, it seems that ongoing media pressure and intense public scrutiny were critical to the finalisation of a proactive compliance deed with the FWO. ${ }^{17}$ This deed, which formalised many of the compliance commitments the franchisor had already adopted, was concluded only after extensive negotiation and continuing controversy about the way in which head office was handling claims following its surprise decision to dismantle the independent panel previously led by Professor Fels. ${ }^{18}$ Another factor which may have further amplified the pressure being placed on 7-Eleven Stores was the Coalition Government's announcement in May 2016 of its intention to introduce new civil remedy provisions 'that capture franchisors ... who fail to deal with exploitation by their franchisees'. ${ }^{19}$

Since then, the Coalition Government has moved to implement this policy by way of the Vulnerable Workers Bill. This Bill is explicitly designed to respond to some of the problems identified by the FWO in the 7-Eleven Inquiry and elsewhere, including the fact that some franchisors may 'operate on a business model based on underpaying workers' ${ }^{20}$ and 'have

16 7-Eleven Inquiry, above n 4, 52-65.

17 See Proactive Compliance Deed between the Commonwealth of Australia (as represented by the Office of the Fair Work Ombudsman) and 7-Eleven Stores Pty Ltd (6 December 2016).

18 Adele Ferguson and Sarah Danckert, '7-Eleven Kills Independent Wage Panel', The Sydney Morning Herald, 11 May 2016.

19 Liberal Party of Australia, 'The Coalition's Policy to Protect Vulnerable Workers', 19 May 2016.

20 Explanatory Memorandum, Vulnerable Workers Bill, 6. 
either been blind to the problem or not taken sufficient action to deal with it once it was brought to their attention'. ${ }^{21}$ In particular, in a submission regarding the Bill, the FWO noted that:

franchisors can be reluctant to proactively engage with the FWO before issues are uncovered, either by the FWO or through the media. Reputational leverage works as a 'push' factor for franchisors to act, but has had limited effect as a general deterrence measure to encourage other franchisors to take reasonable steps to detect non-compliance and support franchisees to be compliant. ${ }^{22}$

These observations reflect the existing sociolegal literature which similarly suggests that, without compelling incentives or coercive sanctions, it is difficult for a regulator to leverage lead firms to genuinely and sustainably engage with softer, voluntary initiatives. ${ }^{23}$ Indeed, the 7-Eleven case summarised above not only illustrates some of the problems of relying on methods of self-regulation, but also underlines a number of the limits of the existing legal framework in making lead firms accountable for conduct taking place in their business networks.

\section{Limitations of Accessorial Liability Provisions}

Under existing law, the principal statutory mechanism for extending liability beyond the direct employer - and holding lead firms to account with respect to employment standards compliance - are the accessorial liability provisions of the $F W A c t$. Essentially, these provisions provide that persons found to be 'involved in' a contravention of the $F W$ Act may be liable under a civil remedy provision, even where they are not the actual employer of the worker whose rights have been breached. Broadly speaking, a person will be taken to be 'involved in' a contravention if the person has:

21 Ibid.

22 Fair Work Ombudsman, Submission to the Senate Education and Employment Legislation Committee Inquiry into the Fair Work Amendment (Protecting Vulnerable Workers) Bill 2017, 6 April 2017.

23 Guy Davidov, 'The Enforcement Crisis in Labour Law and the Fallacy of Voluntarist Solutions' (2010) 26 International Journal of Comparative Labour Law and Industrial Relations 61. See also David Weil, 'Improving Workplace Conditions through Strategic Enforcement' (Report to the Wage and Hour Division, United States Department of Labor, 2010) 87. 
a. aided, abetted, counselled or procured the contravention;

b. induced the contravention (whether by threats or promises or otherwise);

c. been in any way, by act or omission, 'knowingly concerned' in the contravention; or

d. conspired with others to effect the contravention. ${ }^{24}$

The third limb of this definition is arguably the most critical given that it is this subclause which is routinely relied upon by the FWO and other regulators. However, a series of recent cases have set a high bar in relation to satisfying the 'requisite knowledge' requirement under s 550(2)(c) of the FW Act, particularly with respect to contraventions of modern awards. ${ }^{25}$ One of the challenges with using s 550(2)(c) is the need to establish that the accessory had 'actual knowledge' of the essential elements of the contravention. Actual knowledge is said to include 'wilful blindness' but does not generally encompass 'recklessness or negligence'. ${ }^{26}$ Further, constructive knowledge is not sufficient. ${ }^{27}$

The way in which the requisite knowledge requirement has been interpreted and applied by the courts may make it difficult to pin liability on the alleged accessory, especially in complex supply chains, where the lead firm may be more removed from the affected employees and less aware of the precise employment arrangements (e.g. the employment status of the employee, the duties performed, the hours worked etc.). Further, it is not yet clear to what extent it is possible to aggregate the knowledge of multiple officers in larger companies, franchise networks or corporate groups. ${ }^{28}$ Questions arise as to when, and in what circumstances, an accessory's omission to act is likely to 'support the inference of actual knowledge' ${ }^{29}$

\footnotetext{
24 FW Acts 550(2).

25 FW Act s 45. See, for example, FWO v Devine Marine [2015] FCA 370; and Potter v Fair Work Ombudsman [2014] FCA 187.

26 Keller $v$ LED Technologies Pty Ltd [2010] FCAFC 55.

27 Giorgianni v The Queen (1985) 156 CLR 473; Young Investments Group Pty Ltd v Mann (2012) 293 ALR 537, 541.

28 Ingmar Taylor and Larissa Andelman, 'Accessorial Liability under the Fair Work Act' (Paper presented at the Australian Labour Law Association, Sydney, 14-15 November 2014).

29 Fair Work Ombudsman v South Jin Pty Ltd [2015] FCA 1456 [49]. See also Fair Work Ombudsman $v$ Liquid Fuel Pty Ltd [2015] FCCA 2694.
} 
In the view of the FWO, previous cases suggest that '[m]ere knowledge of general non-compliance or suspicions about compliance will not be sufficient to meet the test of section 550(2)(c)' ${ }^{30}$ This appeared to present a real problem for a finding of liability in the 7-Eleven case. The FWO found that a number of individuals employed or engaged by 7-Eleven Stores may have had knowledge of, or capacity to access, essential facts relating to the contraventions committed by the franchisees. However, many of these individuals were unwilling to provide evidence to the FWO about their own conduct or the conduct of others. ${ }^{31}$ The lack of relevant evidence meant that the FWO believed that it was not in a position to prove that 7-Eleven Stores had been 'knowingly concerned' in the contraventions of its franchisees and therefore unable to institute proceedings against 7-Eleven Stores on this basis.

In order to better address these evidentiary issues, the FWO has called for the power to require a person to answer questions on the record in relation to alleged contraventions of the $F W$ Act. $^{32}$ The Vulnerable Workers Bill contains provisions to this effect. ${ }^{33}$ While this may tackle part of the problem, it does not necessarily address some of the more fundamental questions raised by the 7-Eleven case - that is, whether the existing accessorial liability provisions are 'fit for purpose' in terms of achieving the broader policy objective of ensuring employers duly comply with the law, employees are properly paid, and lead firms adopt the necessary measures to make certain this occurs.

In particular, when liability continues to turn on whether a lead firm was 'knowingly concerned' in a contravention committed by another (e.g. an employer entity), the regulatory framework may not properly address the risk of 'counterproductive liability avoidance. ${ }^{34}$ This is where firms seek to rework their contractual relationships to avoid being held liable for employment contraventions. This may involve reducing (rather than expanding) the extent to which they monitor and direct their contractors' or franchisees' compliance practices.

\footnotetext{
30 7-Eleven Inquiry, above n 4, 71.

31 Ibid. 72.

32 Ibid. An alternative way in which to address some of the evidentiary problems facing the FWO - particularly where employment records are absent or inaccurate - is to shift the onus of proof to the alleged wrongdoer. For further discussion, see Hardy, above n 5.

33 Vulnerable Workers Bill Pt 4.

34 Cynthia Estlund, 'Who Mops the Floor at the Fortune 500? Corporate Self-Regulation and the Low Wage Workplace’ (2008) 12(3) Lewis \& Clark Law Review 671, 692.
} 


\section{Possible Reform}

In a separate article, I have surveyed some alternative statutory mechanisms for extending liability for employment contraventions beyond the direct employer entity to other individuals or entities. ${ }^{35}$ These third-party liability regimes have often been principally designed, or primarily used, to tactically target lead firms and combat some of the compliance problems raised by fragmented work structures, such as outsourcing, subcontracting and franchising. In comparison to some of the inherent limits of the accessorial liability provisions of the $F W A c t$, these legislative alternatives are potentially more flexible, and more effective, in achieving the core policy objective of promoting and sustaining widespread workplace relations compliance.

While there are obvious practical advantages and efficiency arguments which support the legal pursuit of lead firms, especially where the direct employer entity is judgment-proof, ${ }^{36}$ the ascription of liability to such firms can be normatively justified on a number of other grounds. For instance, some of the existing literature suggests that making lead firms liable for employment contraventions is defensible where:

a. the lead firm has caused the direct employer to contravene the law;

b. the lead firm has, directly or indirectly, benefited from the contraventions;

c. the lead firm has power to prevent or deter workplace contraventions taking place; and/or

d. the behaviour of the lead firm increases social costs and invites moral sanction - this is especially relevant where the lead firm has made public representations that it is committed to ensuring workplace relations compliance throughout its business, supply chain or franchise network. ${ }^{37}$

The FWO's findings in the 7-Eleven Inquiry lend weight to many of these normative justifications. For example, 7-Eleven Stores has vigorously denied that the viability of the 7-Eleven franchise system is (or was) dependent

\footnotetext{
35 Hardy, above n 5.

36 Brishen Rogers, 'Toward Third-Party Liability for Wage Theft' (2010) Berkeley Journal of Employment and Labour Law 1.

37 See generally Guy Davidov, 'Indirect Employment: Should Lead Companies Be Liable?' (2015)

37 Comparative Labor Law \& Policy Journal 5.
} 
on franchisees underpaying their staff. The FWO also acknowledged that 7-Eleven Stores 'does not directly benefit when a franchisee underpays their workers'. ${ }^{38}$ However, the regulator went on to observe that the franchisor gains an indirect benefit from the (often misguided) perception of store profitability in so far as it allows the store to continue to trade and to generate revenue and other fees for 7 -Eleven Stores. ${ }^{39}$

In addition, the FWO noted, as part of its Inquiry, that 7-Eleven Stores was in a position to prevent workplace contraventions amongst its franchisees, given that it 'controlled the settings of the system in which the franchisee employers operated' 40 and had the resources and capacity to detect and deter franchisee non-compliance. Indeed, the various changes adopted by 7-Eleven Stores in response to public scrutiny, including modifying its business model, enhancing its monitoring and payroll systems and terminating franchise agreements, highlight the regulatory power wielded by the franchisor in this context.

In circumstances where lead firm liability is normatively appropriate, the next key question is an instrumental one: which legal mechanism can and should be used to ascribe liability to lead firms? A key challenge in devising a new model of liability is how best to ensure that it not only achieves the relevant policy objective, but that it remains workable in practice. Drawing on the disparate and distinctive liability models surveyed in my separate article ${ }^{41}$ it seems that one of the most straightforward and promising ways to extend liability is to expand the current statutory definition of what it means to be 'involved in' a contravention under s 550 of the $F W$ Act. For instance, a new limb could be added to the existing statutory provision which does not pivot on knowledge or control - rather, a person (including a lead firm) could be taken to be 'involved in' a contravention under $s 550$ if:

a. the person was in a position to prevent or deter the contravention; and

b. that person has failed to take all reasonably practicable steps to prevent or deter the contravention.

38 7-Eleven Inquiry, above n 4, 38.

39 Ibid. 39.

40 Ibid. 67.

41 Hardy, above n 5. 
In assessing the firm's capacity for prevention and deterrence, the court could be required to have regard to the resources, market position and bureaucratic power held by the lead firm, as well as the nature and duration of the relationship between the lead firm and the direct employer.

In determining whether the lead firm has satisfied the relevant statutory duty, the court may be required to take into account a non-exhaustive range of factors, such as whether the alleged accessory has:

a. adopted rigorous and accountable monitoring practices;

b. engaged only reliable and well-capitalised contractors;

c. ensured that the relevant supply contract, labour hire agreement and/ or franchise model is financially viable;

d. otherwise facilitated or encouraged compliance through tailored financial incentives and commercial sanctions.

While I have used the 7-Eleven example to illustrate some of the regulatory challenges in this context, the proposal for reform outlined above is presented as more than a simple statutory fix for discrete issues raised in the public consciousness. Rather, it is aimed at regulating the foreseeable (and unforeseen) problems that may arise in a range of business networks. ${ }^{42}$ Indeed, one of the most significant gaps in the Vulnerable Workers Bill is that it extends liability for employment contraventions only in franchise networks and corporate groups. Other organisational forms, such as labour hire arrangements and supply chains, are not captured by these provisions.

While this Bill is not without some substantial weaknesses, it represents, and remains, a momentous step forward in enhancing compliance with employment standards regulation in this country. ${ }^{43}$ To a large extent, it addresses key points raised in this article and elsewhere. For example, the proposed provisions allow the court to take into account not only what the responsible franchisor entity (or one of its officers) 'knew' about the contravention of the franchisee entity, but also what it (or the officer) 'could reasonably be expected to have known'. ${ }^{44}$ In short, the provisions

42 Hugh Collins, 'Introduction' in Gunter Teubner, Networks as Connected Contracts (Hart, 2011).

43 For example, one critical issue identified in the submissions to the ongoing inquiry is the definition of 'responsible franchisor entity'. See, for example, Tess Hardy and Joo-Cheong Tham, Submission to the Senate Education and Employment Legislation Committee Inquiry into the Fair Work Amendment (Protecting Vulnerable Workers) Bill 2017, 10 April 2017.

44 Vulnerable Workers Bill s 558B(1)(d)(i) and (ii). 
encompass both actual knowledge and constructive knowledge and, in doing so, potentially address one of the most challenging aspects of the accessorial liability provisions as they currently apply to fragmented work arrangements.

Another critical feature of the Vulnerable Workers Bill is the statutory defence which is embedded in Pt 2. In brief, the Bill provides that the person (i.e. a franchisor, a holding company or a relevant officer) will not contravene the extended liability provisions if, at the time the contravention took place, the 'person had taken reasonable steps to prevent a contravention by the franchisee entity or subsidiary of the same of similar character. ${ }^{25}$ In determining whether a person has taken such 'reasonable steps', the court is directed to have regard to a range of relevant matters, including the size and resources of the franchise or body corporate, any action the person took to inform the employer of the relevant workplace laws and obligations, and any arrangements the person had in place for assessing the employer's ensuing compliance with workplace obligations. Imposing reasonable standards of diligence not only allows the court to undertake a fact-sensitive analysis which takes into account the full range of circumstances, but also seeks to promote the right type of liability avoidance on the part of lead firms - that is, by encouraging franchisors and holding companies to do more (not less) to enhance compliance with workplace laws across their respective business networks.

\section{Conclusion}

The various practical and legal issues identified in the 7-Eleven case suggest that self-regulatory mechanisms are not sufficient, and the current accessorial liability provisions of the FW Act may be inadequate, in addressing some of the most profound problems raised by complex and integrated economic organisations. In seeking to ensure that employees are fully and properly paid in Australia, and in trying to promote lead firms to do more in this respect, it seems that the conception of legal responsibility for employment contraventions may need to be statutorily recalibrated. The Vulnerable Workers Bill represents the first (but, it is hoped, not the last) step in such a direction. 
This text is taken from New Directions for Law in Australia: Essays in Contemporary Law Reform, edited by Ron Levy, Molly O’Brien, Simon Rice, Pauline Ridge and Margaret Thornton, published 2017 by ANU Press, The Australian National University, Canberra, Australia. 